\title{
Digestion of feed amino acids in the rumen and small intestine of dairy cows measured with nylon-bag techniques
}

\author{
BY W. M. VAN STRAALEN*, J. J. ODINGA AND W. MOSTERT \\ DLO-Institute for Animal Science and Health (ID-DLO), PO Box 65, 8200 AB Lelystad, \\ The Netherlands, and \\ Department of Animal Nutrition, Wageningen Agricultural University, Marijkeweg 40, 6709 PG, \\ Wageningen, The Netherlands
}

(Received 2 February 1994 - Revised 1 December 1995 - Accepted 23 January 1996)

\begin{abstract}
The disappearance of total $\mathbf{N}$, non-protein- $\mathbf{N}$ and amino acid- $N$ after washing, rumen incubation and intestinal passage of sugarbeet pulp, maize-gluten feed, maize feed meal, palm kernel meal, soyabean hulls, soyabean meal, grass silage, maize silage and concentrate was measured in four dairy cows using nylon-bag techniques. Disappearance of amino acid-N after washing varied between feedstuffs from 14 to $69 \%$ of feed amino acid-N, and was lower than disappearance of nonprotein-N. For sugarbeet pulp, grass silage and maize silage, washing had a considerable effect on the amino acid profile. Disappearance of amino acid- $\mathrm{N}$ after rumen incubation was also lower than non-protein-N and varied between feedstuffs from 25 to $73 \%$ of feed amino acid-N. Rumen incubation had only a small effect on the amino acid profile of the residue after washing. Disappearance of amino acid-N in the intestine varied between feedstuffs from 70 to $99 \%$ of rumen undegraded amino acid-N, and was higher than the disappearance of non-protein-N. Intestinal incubation showed a considerable effect on the amino acid profile for all feedstuffs. It was concluded that protein that was assumed to escape rumen degradation and was absorbable in the intestine was higher in amino acids and methionine, and lower in non-amino acid-N and glutamic acid and proline compared with protein in the feedstuff.
\end{abstract}

Amino acid digestion: Nylon bags: Feedstuffs: Dairy cows

Modern protein evaluation systems for ruminants describe the supply and requirement of true protein that can be absorbed from the small intestine. To increase the efficiency by which this true protein is used for production purposes, research has been focused on the requirement of first limiting amino acids (Schwab et al. 1992), and results are being incorporated into protein evaluation systems (Rulquin \& Vérité, 1993). To meet requirements, the supply of absorbable individual amino acids can be altered by changing the source of undegraded protein in the diet (Seymour et al. 1990). Before protein is absorbed in the small intestine, it is subjected to microbial fermentation in the rumen and enzymic digestion in the intestine. However, the effect of rumen fermentation on the amino acid profile of undegraded protein is not clear. Some authors found no effect (Varvikko et al. 1983; Weakley et al. 1983; Messman et al. 1992), while others reported different effects for different feedstuffs (Ganev et al. 1979; Hennessey et al. 1983; Rooke, 1985; Crooker et al. 1986; Susmel et al. 1989). Hardly any research has been carried out to study the effect of intestinal digestion on the amino acid profile of undegraded protein (Le Henaff et al. 1988).

*Present address: CLO Institute for Animal Nutrition, "De Schothorst", PO Box 533, 8200 AM Lelystad, The Netherlands. 
The effect of rumen fermentation and small intestine digestion on the amino acid profile of feed protein can be studied using the rumen nylon-bag and mobile nylon-bag techniques (van Straalen et al. 1993). With these techniques dietary ingredients are generally incubated separately. Murphy \& Kennelly (1987) and Stallings et al. (1991) showed that rumen degradation of protein in a concentrate or complete diet mixture could be predicted from the degradation of the ingredients of the concentrate or diet, but for intestinal digestion this was never tested.

The objective of the present study was to determine the effect of washing, rumen incubation and intestinal incubation on the amino acid profile of feedstuffs using nylon-bag techniques, in order to predict the supply of individual amino acids to the animal from rumen undegraded feed. Also, a comparison was made between measured residues after washing, rumen incubation and intestinal incubation of amino acids of a concentrate, and the estimated values from the ingredients of the concentrate.

\section{MATERIALS AND METHODS \\ Experimental animals}

Four dairy cows (Holstein-Friesian) were used, of which three were lactating and one was non-lactating. All animals were fitted with a permanent rumen cannula (Bar Diamond Inc., Pharma, ID, USA) and a T-piece cannula in the distal duodenum. Animals were housed in a tie-stall and fed twice daily ( 08.00 and 20.00 hours) on an equal portion of the daily allowance according to energy and protein requirements. The three lactating cows were fed on a diet consisting of $(\mathrm{g} / \mathrm{kg} \mathrm{DM})$ : maize silage 170 , grass silage 230 , concentrates 600 . The dry cow received a mixture of $(\mathrm{g} / \mathrm{kg} \mathrm{DM})$ : grass silage 600 , maize silage 400 ; with $1 \mathrm{~kg}$ concentrates.

\section{Samples}

Ten feedstuffs were obtained from a parallel feeding experiment: one concentrate, six concentrate ingredients and two roughages. The concentrate contained the following ingredients ( $\mathrm{g} / \mathrm{kg}$ ) sugarbeet pulp (BP) 155, maize-gluten feed (MGF) 300, maize feed meal (MFM) 108, palm kernel expeller (PKE) 125, soyabean hulls (SBH) 50, soyabean meal (SBM) 148. The concentrate also contained $(\mathrm{g} / \mathrm{kg})$ : palm kernels 10 , molasses 80 , minerals 24. Roughages were grass silage (GS) and maize silage (MS). Samples of concentrate ingredients were obtained from the feed factory before pelleting of the concentrate. Samples from the concentrate, grass silage and maize silage were taken during the feeding experiment. Concentrate ingredients and the concentrate were ground to pass a $3 \mathrm{~mm}$ screen. Roughages were chopped in a laboratory cutter to pieces of approximately $10 \mathrm{~mm}$, and kept at $-20^{\circ}$. A portion of each of the samples was dried at $70^{\circ}$, ground to pass a $1 \mathrm{~mm}$ sieve and used for chemical analysis.

\section{Rumen and intestinal incubations}

Nylon-bag incubations in rumen and intestine were carried out according to the procedures of van Straalen et al. (1993). Samples of each feedstuff corresponding to $5 \mathrm{~g}$ DM were weighed into nylon bags $(90 \times 180 \mathrm{~mm}$, polyamide, pore size $41 \mu \mathrm{m}$, porosity $30 \%$; Nybolt, Zurich, Switzerland). For each feedstuff eight bags were incubated for $12 \mathrm{~h}$ in the rumen of each cow. The length of the incubation time was chosen to have close agreement between the residue after $12 \mathrm{~h}$ incubation and the expected effective escape fraction, based 
on rumen degradation characteristics of the same feedstuffs (van Straalen, unpublished results), and calculated according to Ørskov \& McDonald (1979) with a passage rate of $6 \%$ per h (van Straalen et al. 1993). After incubation, bags were rinsed under tap-water and subsequently washed in a domestic washing machine (using 60 litres water at $15^{\circ}$ without spinning). An extra four bags for each feedstuff were not incubated in the rumen and only washed to determine the soluble fractions. Residues were lyophilized, pooled for each animal and feedstuff, and ground to pass a $3 \mathrm{~mm}$ screen. A portion of each of the residues was further ground $(1 \mathrm{~mm})$ and used for chemical analysis.

To determine intestinal digestion, nylon bags $(30 \times 60 \mathrm{~mm}$, the same material as the rumen bags) were filled with $0.5 \mathrm{~g}$ rumen residue DM. Pepsin $(E C 3.4 .23 .1)-\mathrm{HCl}$ incubation (1 g pepsin; Merck, Darmstadt, Germany; 2000 FIP units g, in 1 litre $0.1 \mathrm{M}-\mathrm{HCl}$ ) was carried out for $1 \mathrm{~h}$ at $37^{\circ}$ immediately before intestinal incubation. Bags were introduced into the duodenum (every $20 \mathrm{~min}$ ) via the T-piece cannula (four bags three times hourly) and recovered from the faeces. Recovered bags were rinsed under tap-water and stored at $-20^{\circ}$ until all bags had been retrieved. Bags were washed in a domestic washing machine, using 100 litres water at $40^{\circ}$ with spinning. This procedure was more intensive than the washing procedure of rumen nylon bags because with the latter method not all washable material may have been removed from the bags (van Straalen, unpublished results). Residues were dried at $70^{\circ}$, pooled for each animal and feedstuff, and ground to pass a $1 \mathrm{~mm}$ sieve.

\section{Laboratory analysis}

Feedstuff samples and residues after washing, rumen incubation and intestinal incubation were analysed for $\mathrm{DM}$, ash and Kjeldahl $\mathrm{N}$ according to the standard procedures used at IVVO-DLO (Steg et al. 1990). Residues after washing, rumen incubation and intestinal incubation were pooled for each feedstuff before analysis of amino acids. A single amino acid analysis was carried out according to the Proposed Official Method for Determination of Amino Acids in Animal Feed European Commission 1977, 1979, as described by Van Vuuren et al. (1992). Threonine, serine, valine and isoleucine contents were corrected for incomplete recovery of amino acids after hydrolysis (Slump, 1969). Non-protein-N (NPN) was calculated as total $\mathrm{N}$ minus amino acid-N (AAN). The AAN was further separated into essential AAN (EAAN) and non-essential AAN (NEAAN). Feedstuffs were further analysed for crude fat, starch (Steg et al. 1990), neutral-detergent fibre (NDF), aciddetergent fibre (ADF) and acid-detergent-insoluble N (ADIN; Robertson \& Van Soest, 1981). Apparent digestibility of organic matter was determined in vitro using rumen fluid followed by pepsin- $\mathrm{HCl}$ incubation according to Steg et al. (1990).

\section{Comparison of measured and estimated disappearance of $N$ in concentrate}

The measured disappearance of the concentrate $(\mathrm{Cm})$ after washing, rumen incubation and intestinal incubation was compared with the value estimated from the disappearance of the ingredients of the concentrate and their respective contents (Ce). Disappearance of palm kernel, molasses, and minerals and vitamins were based on tabulated and assumed values.

\section{Statistical analysis}

Differences between feedstuffs in rumen and intestinal disappearance of DM and total N were tested using ANOVA, with feedstuffs as a factor. Differences between feedstuffs for individual AAN disappearances could not be tested, because samples obtained from four 
cows had been pooled per feedstuff before analysis of AAN, resulting in only one observation per amino acid and per feedstuff.

For the comparison of the amino acid profile of the protein in the feedstuff, residue after washing, rumen incubation and intestinal incubation, the method of Guilloteau et al. (1986) was used. In this method the similarity between two amino acid profiles is expressed as the distance in $\chi^{2}$ :

$$
\text { distance in } \chi^{2}=17 \times \sum_{k=1}^{k=17}\left(\mathrm{AAN}_{i k}-\mathrm{AAN}_{j k}\right)^{2} /\left(\left(\mathrm{AAN}_{i k}+\mathrm{AAN}_{j k}\right) / 2\right)
$$

In this equation $\mathrm{AAN}_{i k}$ and $\mathrm{AAN}_{j k}$ are the respective percentages of $\mathrm{N}$ in amino acid $k$ in total AAN of proteins $i$ and $j$ (feedstuff, residue after washing, rumen incubation and intestinal incubation). The same procedure was used to compare the measured and estimated amino acid profiles of the concentrate. A higher distance in $\chi^{2}$ corresponds with a larger difference between the amino acid profiles of the two proteins. Statistical calculations were carried out using the Genstat software (Genstat 5 Committee, 1987).

\section{RESULTS}

\section{Composition of feedstuffs}

The chemical composition and composition of total $\mathrm{N}$ of samples is given in Table 1 and Table 2 respectively. Total $\mathrm{N}$ content in the samples varied between $12.6 \mathrm{~g} / \mathrm{kg} \mathrm{DM}$ for MS and $82.2 \mathrm{~g} / \mathrm{kg} \mathrm{DM}$ for SBM. The content of ADIN in total $\mathrm{N}$ varied from $15 \mathrm{~g} / \mathrm{kg}$ for SBM to $173 \mathrm{~g} / \mathrm{kg}$ for PKE. The lowest contribution of AAN to total $\mathrm{N}$ was observed for $\mathrm{BP}$ $(59 \%)$ and the highest for SBM $(84 \%)$. The percentage of EAAN in AAN varied between 45 (MS) and 60 (PKE).

Compared with the other feedstuffs, BP had a relatively high content of glutamic acid$\mathrm{N}$, and a low content of arginine-N. PKE had very high proportion of arginine- $\mathrm{N}$ in total AAN. Within each class of feedstuffs, amino acid profiles were similar (MGF and MFM; SBH and SBM). Exceptions were the higher glycine- $\mathrm{N}$ and lower glutamic acid- $\mathrm{N}$ and arginine-N contents of SBH compared with those of SBM. The lysine-N and arginine-N contents of MS were low, and those of alanine- $N$ and leucine- $N$ high compared with values for the other feedstuffs.

Table 1. Dry Matter (DM) ( $/ \mathrm{kg})$, organic matter (OM), nitrogen, crude fat, neutral-detergent fibre (NDF), acid-detergent fiber $(A D F)$ and starch contents $(\mathrm{g} / \mathrm{kg} D M)$ and in vitro digestibility coefficient of organic matter (DOM) of feedstuffs

\begin{tabular}{lcccccccccc}
\hline \hline Feedstuff . . & BP & MGF & MFM & PKE & SBH & SBM & GS & MS & Cm & Ce \\
\hline DM (g/kg) & 920 & 901 & 899 & 922 & 902 & 892 & 620 & 339 & 906 & 893 \\
OM & 915 & 939 & 952 & 952 & 949 & 925 & 882 & 954 & 913 & 911 \\
N & $19 \cdot 5$ & $34 \cdot 6$ & $24 \cdot 6$ & $26 \cdot 2$ & $22 \cdot 1$ & $82 \cdot 2$ & $40 \cdot 5$ & $12 \cdot 6$ & $33 \cdot 4$ & $34 \cdot 6$ \\
Crude fat & 7 & 37 & 51 & 103 & 27 & 23 & 43 & 29 & 39 & 40 \\
NDF & 300 & 394 & 311 & 640 & 620 & 123 & 450 & 399 & 323 & 330 \\
ADF & 148 & 97 & 81 & 368 & 436 & 63 & 239 & 208 & 142 & 13 \\
Starch & nd & 200 & 335 & 4 & 8 & 8 & nd & 323 & 109 & 98 \\
DOM (\%) & 89 & 86 & 85 & 70 & 82 & 90 & 79 & 73 & 85 & 85 \\
\hline \hline
\end{tabular}

BP, sugarbeet pulp; MGF, maize gluten feed; MFM, maize feed meal; PKE, palm kernel expeller; SBH, soyabean hulls; SBM, soyabean meal; GS, grass silage; MS, maize silage; $\mathrm{Cm}$, concentrate measured; Ce, concentrate estimated from ingredient composition; nd, not determined. 
Table 2. Acid-detergent-insoluble nitrogen (ADIN), non-protein-N (NPN), amino acid-N $(A A N)$, essential AAN (EAAN), non-essential AAN (NEAAN) and $N$ for individual amino acids in feedstuffs ( $\mathrm{g} / \mathrm{kg}$ total $N)$

\begin{tabular}{lrrrrrrrrrr}
\hline \hline Feedstuff* $\ldots$ & BP & MGF & MFM & PKE & SBH & SBM & GS & MS & Cm & Ce \\
\hline ADIN & 47 & 26 & 59 & 173 & 63 & 15 & 22 & 25 & 45 & 41 \\
NPN & 411 & 269 & 271 & 204 & 210 & 158 & 400 & 389 & 272 & 232 \\
AAN & 589 & 731 & 729 & 796 & 790 & 842 & 600 & 611 & 728 & 768 \\
EAAN & 284 & 378 & 384 & 475 & 406 & 476 & 304 & 278 & 391 & 417 \\
NEAAN & 305 & 353 & 344 & 321 & 384 & 366 & 296 & 333 & 337 & 351 \\
EAAN: & & & & & & & & 27 & 25 & 24 \\
Thr & 25 & 27 & 26 & 22 & 28 & 29 & 27 & 27 \\
Val & 33 & 38 & 35 & 38 & 36 & 37 & 37 & 36 & 35 & 37 \\
Ile & 20 & 21 & 21 & 23 & 24 & 31 & 23 & 23 & 24 & 25 \\
Leu & 26 & 55 & 55 & 40 & 38 & 50 & 39 & 61 & 47 & 48 \\
Tyr & 19 & 14 & 14 & 12 & 22 & 18 & 12 & 10 & 15 & 16 \\
Phe & 12 & 19 & 20 & 20 & 21 & 26 & 21 & 19 & 20 & 21 \\
His & 40 & 52 & 49 & 32 & 52 & 47 & 26 & 34 & 43 & 47 \\
Lys & 51 & 36 & 39 & 29 & 73 & 72 & 38 & 25 & 47 & 52 \\
Arg & 53 & 108 & 117 & 250 & 107 & 158 & 73 & 35 & 128 & 137 \\
Met & 6 & 10 & 9 & 10 & 6 & 7 & 7 & 9 & 8 & 8 \\
NEAAN: & & & & & & & & & \\
Asp & 43 & 40 & 41 & 49 & 63 & 72 & 55 & 40 & 52 & 54 \\
Ser & 37 & 40 & 39 & 37 & 54 & 47 & 33 & 35 & 40 & 42 \\
Glu & 116 & 89 & 86 & 107 & 78 & 106 & 49 & 80 & 95 & 99 \\
Pro & 26 & 57 & 54 & 28 & 38 & 40 & 54 & 54 & 42 & 44 \\
Gly & 38 & 51 & 50 & 50 & 94 & 48 & 45 & 41 & 48 & 50 \\
Ala & 37 & 60 & 60 & 39 & 44 & 42 & 52 & 72 & 48 & 48 \\
Cys & 7 & 16 & 16 & 10 & 13 & 11 & 6 & 11 & 13 & 13 \\
\hline \hline
\end{tabular}

BP, sugarbeet pulp; MGF, maize gluten feed; MFM, maize feed meal; PKE, palm kernel expeller; SBH, soyabean hulls; SBM, soyabean meal; GS, grass silage; $\mathrm{MS}$, maize silage; $\mathrm{Cm}$, concentrate measured; Ce, concentrate estimated from ingredient composition.

*For details of composition, see Table 1.

Except for the higher NPN content, the composition of $\mathrm{Cm}$ was almost identical to that of Ce (Tables 1 and 2).

\section{Disappearance after washing}

Disappearance after washing varied between $17 \%$ for SBH and $45 \%$ for $\mathrm{Cm}$ (Table 3 ). The disappearance of $\mathrm{N}$ varied between feedstuffs from $11 \%$ for SBM to $78 \%$ for MS. For all feedstuffs (except SBM) there was a higher disappearance of NPN after washing than that of AAN. For BP and GS the value for EAAN was considerably lower than that for NEAAN.

The distance in $\chi^{2}$ indicated a large difference in the amino acid profile of the feedstuff and residue after washing for BP, GS and MS (Table 4). This was mainly due to glutamic acid in BP, proline in GS and arginine in MS (Table 3). For the other feedstuffs washing had only a minor effect on the amino acid profile. In general, for threonine and cysteine the levels of disappearance after washing were relatively low, and for proline and histidine they were relatively high. Of the first limiting amino acids, there was a relatively low disappearance of methionine for most feedstuffs while that of lysine was variable. 
Table 3. Disappearance after washing of DM, nitrogen $(N)$, non-protein-N (NPN), amino acid$N(A A N)$, essential $A A N(E A A N)$, non-essential $A A N(N E A A N)$ and $N$ in individual amino acids in feedstuffs (\% of content in feed)*

\begin{tabular}{|c|c|c|c|c|c|c|c|c|c|c|}
\hline Feedstuff $\uparrow$ & BP & MGF & MFM & PKE & SBH & SBM & GS & MS & $\mathrm{Cm}$ & $\mathrm{Ce}$ \\
\hline$\overline{\mathrm{DM}}$ & 44 & 35 & 40 & 19 & 17 & 31 & 35 & 42 & 45 & 41 \\
\hline $\mathbf{N}$ & 50 & 48 & 41 & 22 & 31 & 11 & 54 & 78 & 47 & 30 \\
\hline NPN & 69 & 60 & 100 & 44 & 80 & -2 & 75 & 93 & 81 & 49 \\
\hline AAN & 38 & 44 & 18 & 17 & 17 & 14 & 39 & 69 & 35 & 25 \\
\hline EAAN & 22 & 43 & 17 & 17 & 17 & 12 & 33 & 66 & 33 & 23 \\
\hline NEAAN & 52 & 46 & 19 & 16 & 18 & 15 & 46 & 71 & 37 & 27 \\
\hline \multicolumn{11}{|l|}{ EAAN: } \\
\hline Thr & 25 & 41 & 8 & 14 & 17 & 6 & 37 & 66 & 26 & 19 \\
\hline Val & 22 & 38 & 6 & 13 & 9 & 10 & 39 & 66 & 31 & 19 \\
\hline Ile & 31 & 37 & 7 & 11 & 12 & 6 & 32 & 71 & 30 & 17 \\
\hline Leu & 22 & 40 & 13 & 15 & 16 & 10 & 30 & 74 & 35 & 22 \\
\hline Tyr & 26 & 36 & 5 & 6 & 21 & 10 & 24 & 57 & 26 & 19 \\
\hline Phe & 17 & 37 & 9 & 14 & 25 & 8 & 26 & 64 & 29 & 18 \\
\hline $\mathrm{His}$ & 29 & 45 & 21 & 28 & 33 & 16 & 50 & 76 & 39 & 29 \\
\hline Lys & 24 & 47 & 28 & 13 & 9 & 10 & 36 & 64 & 30 & 21 \\
\hline Arg & 10 & 47 & 24 & 19 & 17 & 18 & 28 & 42 & 35 & 26 \\
\hline Met & 18 & 43 & 21 & -15 & 19 & -7 & 4 & 63 & 15 & 15 \\
\hline \multicolumn{11}{|l|}{ NEAAN: } \\
\hline Asp & 44 & 45 & 20 & 14 & 27 & 10 & 49 & 68 & 33 & 19 \\
\hline Ser & 37 & 50 & 14 & 17 & 19 & 11 & 46 & 70 & 31 & 25 \\
\hline Glu & 76 & 46 & 19 & 18 & 24 & 29 & 40 & 74 & 42 & 35 \\
\hline Pro & 35 & 46 & 23 & 24 & 18 & 13 & 69 & 77 & 44 & 29 \\
\hline Gly & 32 & 41 & 14 & 14 & 9 & 9 & 29 & 61 & 31 & 22 \\
\hline Ala & 39 & 46 & 22 & 15 & 7 & 11 & 43 & 76 & 40 & 27 \\
\hline Cys & 29 & 43 & 24 & 8 & 37 & -2 & 9 & 43 & 30 & 23 \\
\hline
\end{tabular}

BP, sugarbeet pulp; MGF, maize gluten feed; MFM, maize feed meal; PKE, palm kemel expeller; SBH, soyabean hulls; SBM, soyabean meal; GS, grass silage; MS, maize silage; $\mathrm{Cm}$, concentrate measured; Ce, concentrate estimated from ingredient composition.

*For details of procedures, see pp. $84-85$.

$\dagger$ For details of composition, see Table 1 and 2.

Table 4. Distance in $\chi^{2}$ (similarity between two amino acid profiles; Guilloteau et al. 1986) between amino acid-nitrogen (AAN) profiles of feedstuff $(F)$ residue after washing (S), rumen incubation ( $R$ ) and intestinal (I) incubation*

\begin{tabular}{lrrrrrrrrr}
\hline \hline Feedstuff $\dagger \ldots$ & BP & MGF & MFM & PKE & SBH & SBM & GS & MS & Cm \\
\hline F v. S & 239 & 7 & 10 & 7 & 16 & 13 & 82 & 119 & 11 \\
F v. R & 249 & 20 & 27 & 8 & 44 & 18 & 85 & 226 & 11 \\
S v. R & 22 & 11 & 16 & 4 & 35 & 7 & 16 & 71 & 4 \\
F v. I & 748 & 668 & 224 & 209 & 474 & 772 & 171 & 586 & 234 \\
S v. I & 550 & 634 & 223 & 188 & 442 & 717 & 72 & 703 & 209 \\
R v. I & 542 & 617 & 216 & 178 & 262 & 675 & 66 & 677 & 211 \\
\hline \hline
\end{tabular}

BP, sugarbeet pulp; MGF, maize gluten feed; MFM, maize feed meal; PKE, palm kernel expeller; SBH, soyabean hulls; SBM, soyabean meal; GS, grass silage; MS, maize silage; $\mathrm{Cm}$, concentrate measured.

*For details of procedures, see pp. 84-86.

†For details of composition, see Tables 1 and 2. 
The levels of disappearance after washing for N, NPN and AAN of Ce were lower than that for $\mathrm{Cm}$ (Table 3). The estimated amino acid profile of the residue was comparable with that of the measured profile; the distance in $\chi^{2}$ was 4 .

\section{Disappearance after rumen incubation}

Values for the disappearance of DM and $\mathrm{N}$ after $12 \mathrm{~h}$ of rumen incubation for each feedstuff are given in Table 5. There were significant differences between levels of disappearance for both $\mathrm{DM}$ and $\mathrm{N}$ between feedstuffs. The lowest level of $\mathrm{DM}$ disappearance was observed for PKE (39\%) and the highest for BP (78\%). For $\mathrm{N}$ the level of disappearance varied from $24 \%$ for PKE to $76 \%$ for GS. For PKE the disappearance of AAN was higher than that of NPN; for MGF, MFM and SBH the differences were small, and for the remaining feedstuffs the disappearance of AAN was lower than that of NPN. For BP, PKE, GS, MS and Cm, NEAAN was degraded further in the rumen than EAAN, while differences were small for the other feedstuffs.

Table 5. Disappearance after $12 \mathrm{~h}$ rumen incubation of $D M$, nitrogen $(N)$, non-protein- $N$ $(N P N)$, amino acid-N (AAN), essential $A A N(E A A N)$, non-essential $A A N$ (NEAAN) and $N$ in individual amino acids in feedstuffs (\% of content in feed $)^{*}$

\begin{tabular}{|c|c|c|c|c|c|c|c|c|c|c|}
\hline Feedstuff $\uparrow \ldots$ & BP & MGF & MFM & PKE & SBH & SBM & GS & MS & $\mathrm{Cm}$ & $\mathrm{Ce}$ \\
\hline$\overline{\mathrm{DM}_{\ddagger}^{\ddagger}}$ & $78^{f}$ & $64^{\mathrm{de}}$ & $61^{\text {cd }}$ & $39^{\mathrm{a}}$ & $41^{a}$ & $69^{\mathrm{e}}$ & $54^{b}$ & $57^{\mathrm{bc}}$ & $69^{e}$ & 66 \\
\hline $\mathrm{N}_{\ddagger}^{+}$ & $74^{\mathrm{de}}$ & $73^{\mathrm{cd}}$ & $61^{\mathrm{b}}$ & $24^{\mathrm{a}}$ & $62^{b}$ & $59^{\mathrm{b}}$ & $76^{e}$ & $74^{\mathrm{de}}$ & $69^{c}$ & 62 \\
\hline NPN & 89 & 73 & 60 & 18 & 61 & 72 & 83 & 79 & 83 & 69 \\
\hline AAN & 63 & 73 & 61 & 25 & 62 & 57 & 72 & 71 & 64 & 60 \\
\hline EAAN & 55 & 72 & 60 & 24 & 63 & 57 & 68 & 66 & 63 & 58 \\
\hline NEAAN & 71 & 73 & 61 & 27 & 62 & 57 & 76 & 75 & 66 & 63 \\
\hline \multicolumn{11}{|l|}{ EAAN: } \\
\hline Thr & 60 & 70 & 56 & 19 & 66 & 53 & 73 & 66 & 60 & 58 \\
\hline Val & 60 & 72 & 59 & 23 & 60 & 52 & 73 & 74 & 63 & 58 \\
\hline Ile & 56 & 67 & 52 & 17 & 58 & 52 & 67 & 69 & 59 & 54 \\
\hline Leu & 49 & 68 & 51 & 20 & 62 & 54 & 68 & 80 & 62 & 56 \\
\hline Tyr & 66 & 68 & 52 & 14 & 60 & 52 & 67 & 63 & 60 & 56 \\
\hline Phe & 49 & 69 & 53 & 22 & 66 & 55 & 70 & 69 & 61 & 56 \\
\hline His & 65 & 78 & 68 & 27 & 59 & 56 & 67 & 73 & 67 & 64 \\
\hline Lys & 58 & 71 & 62 & 13 & 57 & 59 & 66 & 40 & 60 & 59 \\
\hline Arg & 40 & 76 & 67 & 28 & 69 & 62 & 66 & 41 & 64 & 59 \\
\hline Met & 45 & 66 & 51 & 1 & 55 & 45 & 60 & 69 & 61 & 49 \\
\hline \multicolumn{11}{|l|}{ NEAAN: } \\
\hline Asp & 63 & 71 & 59 & 24 & 70 & 58 & 77 & 65 & 64 & 64 \\
\hline Ser & 68 & 73 & 61 & 25 & 57 & 51 & 75 & 71 & 63 & 59 \\
\hline Glu & 85 & 74 & 61 & 32 & 70 & 63 & 72 & 80 & 69 & 67 \\
\hline Pro & 57 & 75 & 62 & 24 & 59 & 60 & 86 & 80 & 67 & 64 \\
\hline Gly & 57 & 72 & 63 & 26 & 53 & 52 & 70 & 66 & 62 & 58 \\
\hline Ala & 62 & 72 & 59 & 22 & 63 & 52 & 74 & 81 & 66 & 61 \\
\hline Cys & 55 & 72 & 66 & 21 & 69 & 51 & 60 & 64 & 69 & 60 \\
\hline
\end{tabular}

$a, b, c, d, e, f$ Values in the same row with different superscript letters were significantly different $(P<0.05)$.

BP, sugarbeet pulp; MGF, maize gluten feed; MFM, maize feed meal; PKE, palm kernel expeller; SBH, soyabean hulls; SBM, soyabean meal; GS, grass silage; MS, maize silage; $\mathrm{Cm}$, concentrate measured; Ce, concentrate estimated from ingredient composition.

*For details of procedures, see pp. 84-85.

†For details of composition, see Tables 1 and 2.

†No. of replicates 4; SED: DM 2.4, N 3.3 (excluded Ce). 
The amino acid profiles of the residues after rumen incubation were different from those of the original feed for BP, GS and MS, but comparable to those after washing, as indicated by the distance in $\chi^{2}$ (Table 4). In general, glutamic acid showed high levels of disappearance (Table 5). For arginine the levels of disappearance were relatively low for $\mathrm{BP}$ and MS, but relatively high for MGF, MFM and SBM. Of the first limiting amino acids, for all feedstuffs, especially PKE, methionine was relatively undegradable, while the residual lysine was relatively high in PKE and MS.

For Ce the levels of disappearance of total N, NPN and AAN in the rumen were lower than those for $\mathrm{Cm}$ (Table 5), but the amino acid profiles of the rumen residues were comparable (distance in $\chi^{2}: 2$ ).

\section{Intestinal disappearance}

The disappearance of DM and $\mathrm{N}$, expressed as a percentage of the rumen residue, differed significantly between feedstuffs and varied from $20 \%$ for MS to $88 \%$ for SBM and from $64 \%$ for MS and SBH to $99 \%$ in SBM, respectively (Table 6). The disappearance of NPN varied between $38 \%$ for SBH and $97 \%$ for SBM, and for all feedstuffs was lower than that of AAN, which varied between $70 \%$ for SBH and $99 \%$ for SBM. EAAN had a higher level of disappearance in the intestine than NEAAN.

Judged by the distance in $\chi^{2}$, intestinal incubation of rumen residues resulted in a considerable change in amino acid profile (Table 4). This difference was highest for MS, SBM, MGF and BP. For most feedstuffs arginine had a relatively high level of disappearance, and glycine and cysteine a relatively low level of disappearance, compared with other amino acids (Table 6). The disappearance of methionine was relatively high in MFM and PKE, while lysine disappearance was relatively low in MGF, MFM and SBH. In MS an extremely low level of histidine disappearance was observed.

The intestinal levels of disappearance of the different components of total $\mathrm{N}$ for Ce were lower than those for $\mathrm{Cm}$, but the amino acid profiles were similar (Table 6; distance in $\chi^{2}$ was 25 ).

\section{DISCUSSION}

\section{Feedstuff composition}

The NPN values for concentrate ingredients were generally higher than those given in the Dutch Feedstuff Table (Centraal Veevoederbureau, 1991). Only part of this difference could be attributed to tryptophan, which was not determined in our experiment. There were no differences in EAAN:NEAAN and the profile of individual amino acids between tabulated values and values measured in our experiment. For BP only there was a lower NPN, higher glutamic acid-N and lower aspartic acid-N content than that given by the Centraal Veevoederbureau (1991). The NPN content in BP increases with the inclusion of molasses. The $\mathrm{N}$ in molasses consists of about $70 \% \mathrm{NPN}$ and $30 \%$ AAN, which is mainly aspartic acid-N and glutamic acid-N (Centraal Veevoederbureau 1991). The level of inclusion of molasses in the BP in our experiment was not known, but based on NDF content it was comparable with the quality of BP with the highest sugar content and, thus, highest inclusion of molasses.

The AA profile of GS observed in our experiment differed from that published by Rooke et al. (1984) and Syrjälä-Qvist et al. (1984 a,b). The total and individual EAAN in MS was lower than observed by Le Henaff et al. (1988). One can speculate that these differences may be due to differences in the contents of different types of protein, related to species, fertilization and maturity. 
Table 6. Disappearance in the intestine of $D M$, nitrogen $(N)$, non-protein- $N(N P N)$, amino acid-N (AAN), essential $A A N$ (EAAN), non-essential $A A N(N E A A N)$ and $N$ in individual amino acids in feedstuffs (\% of $12 \mathrm{~h}$ rumen residue)*

\begin{tabular}{|c|c|c|c|c|c|c|c|c|c|c|}
\hline Feedstuff $† \ldots$ & BP & MGF & MFM & PKE & SBH & SBM & GS & MS & $\mathrm{Cm}$ & $\mathrm{Ce}$ \\
\hline$\overline{\mathrm{DM}}$ & $70^{b}$ & $39^{e}$ & $47^{d}$ & $52^{\mathrm{c}}$ & $30^{f}$ & $88^{\mathrm{a}}$ & $43^{\mathrm{de}}$ & $20^{g}$ & $51^{\text {cd }}$ & 52 \\
\hline $\mathrm{N} \ddagger$ & $86^{\mathrm{c}}$ & $84^{b}$ & $86^{\mathrm{cd}}$ & $85^{\mathrm{cd}}$ & $64^{e}$ & $99^{\mathrm{a}}$ & $87^{\mathrm{bc}}$ & $64^{e}$ & $89^{b}$ & 85 \\
\hline NPN & 64 & 73 & 83 & 70 & 38 & 97 & 78 & 50 & 71 & 67 \\
\hline AAN & 91 & 87 & 87 & 90 & 70 & 99 & 91 & 72 & 92 & 89 \\
\hline EAAN & 92 & 89 & 88 & 91 & 74 & 99 & 91 & 74 & 93 & 91 \\
\hline NEAAN & 90 & 86 & 85 & 88 & 67 & 99 & 90 & 69 & 91 & 88 \\
\hline \multicolumn{11}{|l|}{ EAAN: } \\
\hline Thr & 90 & 79 & 79 & 88 & 81 & 100 & 90 & 72 & 90 & 86 \\
\hline Val & 99 & 88 & 88 & 89 & 74 & 99 & 90 & 71 & 92 & 92 \\
\hline Ile & 91 & 89 & 90 & 88 & 82 & 100 & 91 & 75 & 94 & 91 \\
\hline Leu & 91 & 90 & 92 & 88 & 83 & 100 & 91 & 75 & 94 & 91 \\
\hline Tyr & 89 & 86 & 88 & 88 & 61 & 99 & 92 & 86 & 91 & 87 \\
\hline Phe & 91 & 82 & 90 & 89 & 83 & 100 & 91 & 72 & 94 & 89 \\
\hline His & 86 & 81 & 85 & 88 & 62 & 99 & 89 & 5 & 91 & 85 \\
\hline Lys & 93 & 81 & 82 & 90 & 63 & 99 & 92 & 77 & 91 & 88 \\
\hline Arg & 93 & 100 & 90 & 94 & 85 & 100 & 92 & 100 & 95 & 94 \\
\hline Met & 93 & 89 & 92 & 92 & 82 & 100 & 92 & 77 & 93 & 91 \\
\hline \multicolumn{11}{|l|}{ NEAAN: } \\
\hline Asp & 92 & 86 & 87 & 89 & 82 & 100 & 91 & 73 & 94 & 89 \\
\hline Ser & 86 & 86 & 86 & 88 & 65 & 99 & 90 & 73 & 91 & 87 \\
\hline Glu & 92 & 91 & 92 & 90 & 80 & 100 & 91 & 76 & 95 & 92 \\
\hline Pro & 89 & 81 & 85 & 86 & 59 & 99 & 93 & 65 & 89 & 85 \\
\hline Gly & 82 & 79 & 79 & 81 & 53 & 98 & 87 & 63 & 84 & 79 \\
\hline Ala & 100 & 89 & 77 & 88 & 75 & 99 & 90 & 69 & 92 & 91 \\
\hline Cys & 84 & 82 & 82 & 86 & 67 & 99 & 78 & 53 & 88 & 84 \\
\hline
\end{tabular}

a,b,c,d,e,f,g Values in the same row with different superscript letters were significantly different $(P<0 \cdot 05)$.

BP, sugarbeet pulp; MGF, maize gluten feed; MFM, maize feed meal; PKE, palm kernel expeller; SBH, soyabean hulls; SBM, soyabean meal; GS, grass silage; MS, maize silage; $\mathrm{Cm}$, concentrate measured; Ce, concentrate estimated from ingredient composition.

*For details of procedures, see pp. 84-85.

For details of composition, see Tables 1 and 2 .

$\$$ No. of replicates 4; SED: DM 3.8, N 2.4 (excluded Ce).

\section{Solubility}

For BP only there was a large difference in the soluble $\mathrm{N}$ fraction when comparing our values with those of van Straalen \& Tamminga (1990). This difference can be explained by the high level of molasses included. For all feedstuffs (except SBM), NPN was relatively more soluble than AAN. Furthermore, MacGregor et al. (1978) observed a higher solubility of NPN in a modified Burroughs mineral buffer compared with AAN for a large range of feedstuffs. Depending on the feedstuff, NPN consists of $\mathrm{NO}_{3}, \mathrm{NH}_{3}$, purine, RNA and DNA, which are relatively soluble or easily degradable in the rumen (Greife, 1984; Tamminga, 1986). There was a positive relationship between the NPN content and the soluble N (SN) fraction: $\mathrm{SN}(\mathrm{g} / \mathrm{kg} \mathrm{N})=-76+1.74 \times \mathrm{NPN}(\mathrm{g} / \mathrm{kg} \mathrm{N})\left(r^{2} 0.74 ; n 9\right)$. In addition to NPN, some of the AAN was also washed out of the nylon bags. The solubility of total AAN in BP was higher than that observed by MacGregor et al. (1978), who also reported a higher solubility for glutamic acid compared with the other amino acids. The high solubility of glutamic acid in BP can be explained by the difference in amino acid 
profile and solubility between BP and added molasses, as discussed previously. For MFM and SBM the solubilities of total AAN were comparable with those of MacGregor et al. (1978), but those for individual AAN were different.

\section{Rumen degradation}

For most feedstuffs the residual $\mathrm{N}$ after $12 \mathrm{~h}$ rumen incubation was comparable with the effectively-fermented fraction calculation from degradation characteristics in the rumen (W.M. van Straalen, unpublished results) and an assumed passage rate of $6 \%$ per h (\%; BP 73, MGF 70, MFM 63, PKE 45, SBH 57, SBM 56, GS 78, MS 78, Cm 67). These values were also similar to the effective escaped $\mathrm{N}$ given by Centraal Veevoederbureau (1991). For PKE a higher value was observed; this could be due to the relatively long lag-time before the onset of the degradation, resulting in a large residue after $12 \mathrm{~h}$ incubation time in the present experiment. (A. Steg, unpublished results).

The further disappearance of $\mathrm{N}$ after rumen incubation (Table 5) when compared with that after washing (Table 3) varied between feedstuffs. For MS no extra disappearance was measured $(-4 \%)$, while for SBM another $48 \%$ disappeared after rumen incubation. For NPN this variation ranged from $-40 \%$ for MFM to $74 \%$ in SBM, and for AAN, $2 \%$ for MS and $45 \%$ for SBH. From the higher distance in $\chi^{2}$ between the feedstuff and residue after washing, compared with that for the residue after washing and rumen incubation, it can be concluded that depending on the feedstuff the amino acid profile is more influenced by washing than by rumen degradation. This agrees with the conclusion of MacGregor et al. (1978) that the amino acid profile of the insoluble residue can be regarded as more representative of that of escaped protein than that of the feedstuff.

In our study methionine in SBM was relatively undegradable compared with other amino acids, which is in agreement with results obtained by Crooker et al. (1987), Le Henaff et al. (1988) and Mir et al. (1984), but contrasts with those of Susmel et al. (1989). Relatively high degradability of arginine and glutamic acid in SBM was also reported by Crooker et al. (1986,1987). According to the literature, tyrosine in SBM was relatively undegradable (Ganev et al. 1979; Hennessy et al. 1983; Varvikko et al. 1983), and histidine relatively degradable (Varvikko et al. 1983; Mir et al. 1984); we were unable to confirm these observations in our experiment. Also, our finding that methionine in GS was relatively undegradable disagreed with the findings of Rooke et al. (1984), although the low degradation of proline was similar. Degradation of individual amino acids in MS was in line with the findings of Le Henaff et al. (1988).

Changes in the amino acid profile after rumen fermentation were mainly observed with BP and MS (Table 4). Since the total N content of BP and MS is low, microbial contamination of rumen residues can have a large effect on the amino acid profile of the residues. The high residues of lysine and arginine in both BP and MS are an indication that these residues contained microbial protein, which has a relatively high content of those amino acids (Rooke et al. 1984). Diaminopimelic acid (DAPA) was used to estimate microbial contamination. However, the DAPA content of both feedstuffs and residues was generally below the detection level of $0.50 \mathrm{~g} / \mathrm{kg} \mathrm{DM}$, and if it was higher a large variation was observed. The DAPA content, therefore, was assumed to be unsuited for the estimation of microbial contamination. An attempt was made to estimate microbial contamination according to van Bruchem et al. (1985), by means of comparison of amino acid profiles of the feed, microbial protein (Rooke et al. 1984) and rumen residue. The method of van Bruchem et al. (1985) incorrectly assumes that the amino acid profile of feed does not change during rumen incubation and, therefore, the amino acid profile of the insoluble 
residue was used instead of that of the feed. Values for estimated microbial contamination were (\%): 27, 0, 10, 4, 0, 5, 12, 36 and 0 of total AAN for BP, MGF, MFM, PKE, SBH, SBM, GS, MS and Cm respectively. Estimated values for contamination agreed with those observed for concentrate ingredients (Crooker et al. 1986, 1987) but were lower than those reported for roughages (Nocek \& Grant, 1985; Messman et al. 1992). If the amino acid profile of the feed was used, estimated contamination values for all feedstuffs were higher, especially for BP, GS and MS (78, 53 and $58 \%$ respectively). The latter feedstuffs also showed high differences between the amino acid profile of the feedstuff and residue after washing. This indicates the importance of using the amino acid profile of the insoluble residue rather than that of the feed. It was concluded that microbial contamination cannot be neglected, at least for BP, GS and MS.

In addition to the differences in solubility and microbial contamination, changes in the amino acid profile after rumen incubation can also be caused by the difference in degradation rates between individual amino acids. Messman et al. (1992) observed only small differences between individual amino acid degradation rates with bromegrass (Bromis inermis) hay, while with grass silage, Rooke et al. (1984) found consistent differences in degradation rates between individual amino acids. Differences in the degradation rates of individual amino acids might be dependent on the content of the different protein classes (albumin, globulin etc.) in the feedstuff and their respective physical properties (solubility, structure) and amino acid composition (Messman et al. 1992).

\section{Intestinal disappearance}

Because mobile nylon bags were recovered from the faeces, the disappearance of $\mathrm{N}$ is the sum of its disappearance in the small intestine and large intestine. Although the latter was not measured in our experiment, other studies indicate that large-intestine fermentation has only a limited effect on total intestinal disappearance, both in nylon bag (Hvelplund, 1985; Voigt et al. 1985) and in in vivo experiments (van Straalen \& Tamminga, 1990).

Total $\mathrm{N}$ disappearance from mobile nylon bags containing concentrate ingredients were similar to the digestibility coefficients in the small intestine given by Centraal Veevoederbureau (1991). The disappearance of total AAN in the intestine was higher than that of total $\mathrm{N}$ and showed a close relationship: disappearance of $A A N(\mathrm{~g} / \mathrm{g})=$ $0.18+0.82 \times$ disappearance of total $\mathrm{N}\left(\mathrm{g} / \mathrm{g} ; r^{2} 0.98 ; n 9\right)$. With this equation data from grass silage and hay from Varvikko \& Vanhatalo (1991) showed a reasonable fit $\left(r^{2}\right.$ between predicted and measured disappearance of AAN was 0.77). If this relationship is valid also for other feedstuffs, it can be used to predict the AAN disappearance from total $\mathrm{N}$ disappearance in mobile nylon bags.

The disappearance of NPN was generally lower than the intestinal digestibility of nucleic acids mentioned by Greife (1984). This finding indicates that NPN in rumenundegraded $\mathrm{N}$ is mainly linked to components that are indigestible in the intestine. Combined with the observations for NPN disappearance in the rumen, this leads to the conclusion that NPN in feedstuffs consists of two fractions: one that is highly soluble in the rumen, and one that is linked to cell walls and is indigestible. Furthermore, Hof et al. (1990) observed a decrease of NPN in rumen residues with short incubation periods and an increase with long incubation periods. The ADIN content as a measure of indigestible $\mathrm{N}$ was proposed by Robertson \& Van Soest (1981). However, the relationships between the indigestible $\mathrm{N}$ or indigestible NPN measured with mobile nylon bags and the ADIN content were poor (Fig. 1). Webster et al. (1984) proposed the estimation of small intestinal 


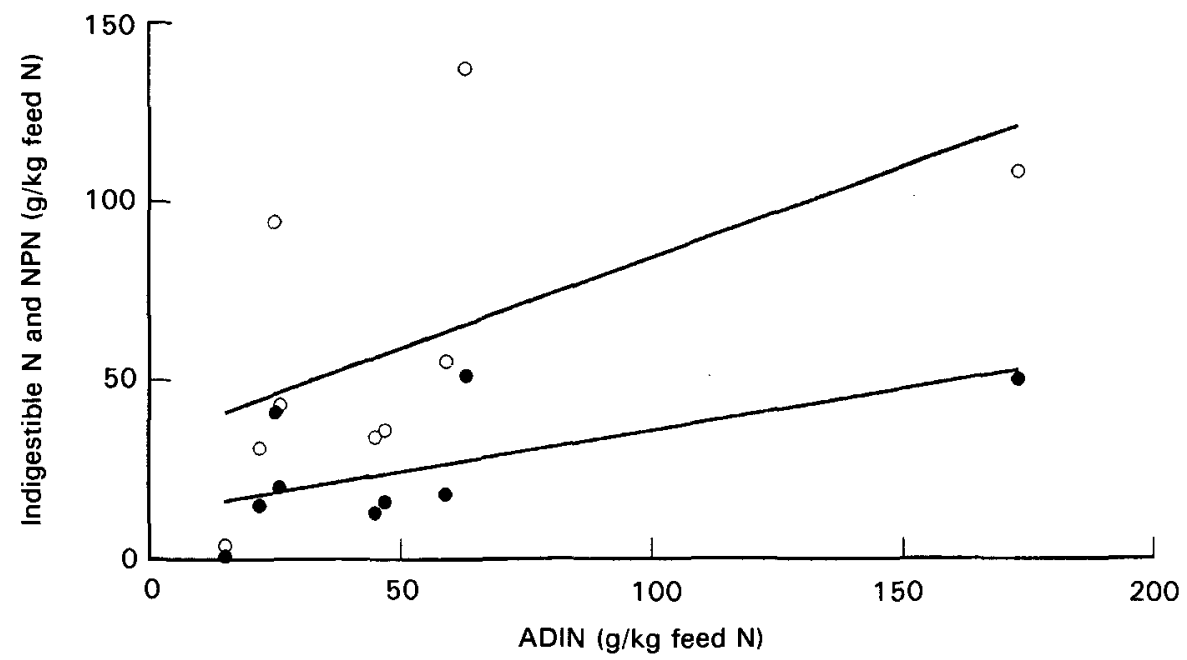

Fig. 1. Relationship between indigestible nitrogen $(O)$, indigestible non-protein-N (NPN; $\odot$ ) measured with nylon bag incubations and acid-detergent-insoluble $\mathrm{N}$ (ADIN; all expressed as $\mathrm{g} / \mathrm{kg}$ feed- $\mathrm{N}$ ). Regression equations: $\mathrm{IN}=33.5+0.505 \times \mathrm{ADIN}\left(r^{2} 0.32, \mathrm{SE}\right.$ of estimate $38.1 ; \mathrm{NPN}=12.8+0.230 \times \mathrm{ADIN}\left(r^{2} 0.39\right.$, SE of estimate 14.9).

digestibility of total $\mathrm{N}$ (dUN) from ADIN and undegraded dietary $\mathrm{N}$ (UDN): $\mathrm{dUN}=0.9 \times(\mathrm{UDN}-\mathrm{ADIN}) / \mathrm{UDN}$. This approach was adopted in the metabolizable protein system (Agricultural and Food Research Council, 1992). There was no relationship between dUN calculated for feedstuffs in our experiment (from Tables 2 and 5) and the disappearance of total $\mathrm{N}$ from nylon bags in the intestine (Table $6 ; r^{2} 0.19$ ). For most samples the disappearance of N from nylon bags was higher than dUN (except for SBH and MS). Using mobile-nylon-bag data will, therefore, result in a higher predicted supply of absorbable feed $\mathrm{N}$ compared with the approach of Webster et al. (1984). This conclusion confirms the comparison of these methods that can be carried out using data from other feedstuffs as presented by Agricultural and Food Research Council (1992).

For all feedstuffs intestinal incubation had a considerable effect on the amino acid profile. For most feedstuffs this could be explained by the relatively high disappearance of arginine and low disappearance of glycine. Thus, these amino acids accounted for the difference between the intestinal disappearance of EAAN and NEAAN. The high disappearance of arginine could be the result of the action of trypsin (EC 3.4.21.4), which is an endopeptidase that hydrolyses only lysine and arginine-bonds (Stryer, 1988). Le Henaff et al. (1988), however, did not find a higher arginine disappearance in the intestine. The theory also does not explain the variable disappearances obtained for lysine. The low disappearance of glycine might be an indication of contamination with endogenous protein which has a high glycine content (Laplace et al. 1985).

\section{Predicted supply of absorbable feed amino acids to the animal}

From the disappearance of AAN, in terms of the individual amino acids, from nylon bags in the rumen (Table 4) and intestine (Table 6), the supply to the animal of AAN in terms of the individual amino acids in the feed that are absorbed in the small intestine can be predicted. It was assumed that the residue after rumen incubation was representative of the escape fraction and all AAN that disappeared from the mobile nylon bags was absorbed in the small intestine. The predicted supply of AAN (expressed as a percentage of AAN in the 
feed) varied between feedstuffs from 21 to $67 \%$ and for all feedstuffs was higher than the supply of NPN (7-57\%). The predicted supply of EAAN (25-69\%) was higher than that of NEAAN (17-64\%). The predicted supply of methionine was higher than values for other amino acids for all feedstuffs but CS. For BP, GS and CS lysine had the second highest supply. Also, isoleucine, leucine, tyrosine and arginine had a high supply for several feedstuffs. Of the EAAN, histidine showed the lowest supply for MGF, MFM and CS. For most feedstuffs the supply of glutamic acid and proline was the lowest of the NEAAN. Also, other NEAAN showed poor supply compared with EAAN.

\section{Measured and estimated AAN fermentation and digestion of concentrate}

No explanation can be found for the higher AAN content of Ce compared with that of $\mathrm{Cm}$. The lower disappearance after rumen incubation of all $\mathrm{N}$ fractions of Ce compared with those of $\mathrm{Cm}$ was mainly due to the lower soluble $\mathrm{N}$ fraction. A reason for this can be the treatment (grinding, mixing and pelleting) of concentrate ingredients during the manufacturing process of the concentrate, which might have reduced particle sizes, resulting in a higher disappearance of $\mathrm{N}$ from nylon bags in the washing machine. Results are in contrast to those of Murphy \& Kennelly (1987), who observed similar measured and estimated protein degradation in the rumen: this can be explained by the absence of pelleting of concentrate mixtures. In contrast to the rumen residues, intestinal disappearance of all $\mathrm{N}$ fractions in the concentrate could be estimated from the values obtained with ingredients. Since the rumen residues were higher, the estimated absorption of AAN in terms of the individual amino acid were higher than the measured values. The amino acid profile of undegraded AAN or small intestine-digestible AAN in concentrates could be estimated very well from that of the individual concentrate ingredients.

\section{Conclusions}

Although differences between feedstuffs do exist, it can be concluded that AAN was less degradable in the rumen than NPN, and that EAAN was less degradable than NEAAN. Dependent on the feedstuff, rumen incubation has a pronounced effect on the amino acid profile, which was mainly due to the difference in solubility of the amino acids. Intestinal incubation resulted in a considerable change in the amino acid profile of the indigestible residue. It can be concluded that feed protein that is assumed to be absorbed from the small intestine is higher in EAAN, especially methionine- $N$ and lysine- $N$, and lower in NEAAN, especially glutamine- $\mathrm{N}$ and proline- $\mathrm{N}$, than protein in the feedstuff.

The authors are grateful to S. Tamminga (Agricultural University Wageningen) and A. M. van Vuuren for their contribution to the discussion and critically reading the manuscript. They also greatly appreciate the assistance of $\mathrm{R}$. Terluin and his team during the experiment. This study was financed partly by Financieringsoverleg Mest- en Ammoniakonderzoek (Fund for Manure and Ammonia Research).

\section{REFERENCES}

Agricultural and Food Research Council (1992). Nutritive requirements of ruminant animals: protein. Nutrition Abstracts and Reviews 62B, $788-835$.

Centraal Veevoederbureau. (1991). Veevoedertabel (Dutch Feeding Tables). Lelystad: Centraal Veevoederbureau. 
Crooker, B. A., Clark, J. H., Shanks, R. D. \& Fahey, G. C. (1987). Effects of numinal exposure on the amino acid profile of feeds. Canadian Journal of Animal Science 67, 1143-1148.

Crooker, B. A., Clark, J. H. Shanks, R. D. \& Hatfield, E. E. (1986). Effects of ruminal exposure on the amino acid profile of non treated and formaldehyde treated soybean meal. Journal of Dairy Science 69, $2628-2657$.

European Commission (1977). Proposed Official Method for Determination of Amino Acids in Animal Feed. Dir 77/I01/EEC. Strasbourg: European Commission.

European Commission (1979). Proposed Official Method for Determination of Amino Acids in Animal Feed. Dir 79/373/EEC. Strasbourg: European Commission.

Ganev, G., Ørskov, E. R. \& Smart, R. (1979). The effect of roughage or concentrate feeding and rumen retention time on total degradation of protein in the rumen. Journal of Agricultural Science, Cambridge 94, 651-656.

Genstat 5 Committee (1987). Genstat 5 Reference Manual. Oxford: Clarendon Press.

Greife, H. A. (1984). Enteraler und intermediärer Nukleinsäurenstoffwechsel (Nucleic acids in the intestine and metabolism). Ubersicht zur Tierernährung 12, 1-44.

Guilloteau, P., Toullec, R. \& Grongnet, J. F. (1986). Digestion of milk, fish and soya-bean protein in the preruminant calf: flow of digesta, apparent digestibility at the end of the ileum and amino acid composition of ileal digesta. British Journal of Nutrition 55, 571-592.

Hennessy, D. W., Lee, G. J. \& Williamson, P. J. (1983). Nitrogen loss from protein meals held in terylene bags in the rumen of cattle and the nutritive value of the residues. Australian Journal of Agricultural Research 34, $453-467$.

Hof, G., Kouwenberg, W. J. A. \& Tamminga, S. (1990). The effect of washing procedure on the estimation of the in situ disappearance of amino acids from feed protein. Netherlands Journal of Agricultural Science 38, 719-742.

Hvelplund, T. (1985). Digestibility of rumen microbial and undegraded dietary protein estimated in the small intestine of sheep and by the in sacco procedure. Acta Agriculturae Scandinavica Suppl. 25, 132-144.

Laplace, J.-P., Darcy-Vrillon, B., Duval-Iflah, Y. \& Raibaud, P. (1985). Proteins in the digesta of the pig: amino acid composition of endogenous, bacterial and fecal fractions. Reproduction Nutrition Développement 6, 1083-1099.

Le Henaff, L., Rulquin, H. \& Peyraud, J. L. (1988). Etude de la disparition des acides amines alimentaires dans le rumen et dans l'intestin a l'aide de la methode des sachets nylon (A study of amino acid disappearance from feedstuffs in the rumen and intestine measured with the nylon bag method). Reproduction Nutrition Développement 28, Suppl 1, 133-134.

MacGregor, C. A., Sniffen, C. J. \& Hoover, W. H. (1978). Amino acid profiles of total and soluble protein in feedstuffs commonly fed to ruminants. Journal of Dairy Science 61, 566-573.

Messman, M. A., Weiss, W. P. \& Erickson, D. O. (1992). Effects of nitrogen fertilization and maturity of bromegrass on nitrogen and amino acid utilization by cows. Journal of Animal Science 70, 566-575.

Mir, Z., MacLeod, G. K., Buchanan-Smith, J. G., Grieve, D. G. \& Grovum, W. L. (1984). Methods for protecting soybean and canola proteins from degradation in the rumen. Canadian Journal of Animal Science 64, 853-864.

Murphy, J. J. \& Kennelly, J. J. (1987). Effect of protein concentration and protein source on the degradability of dry matter and protein in situ. Journal of Dairy Science 70, 1841-1849.

Nocek, J. E. \& Grant, A. L. (1985). Characterisation of in situ nitrogen and fiber digestion and bacterial nitrogen contamination of hay crop forages preserved at different dry matter percentages. Journal of Animal Science 64, 552-564.

Ørskov, E. R. \& McDonald, I. (1979). The estimation of protein degradability in the rumen from incubation measurements weighted according to rate of passage. Journal of Agricultural Science, Cambridge 92, 499 503.

Robertson, J. B. \& Van Soest, P. J. (1981). The detergent system of analysis and its application to human foods. In The Analysis of Dietary Fiber in Food, pp. 123-158 [W. P. T. James and O. Theander, editors]. New York: Marcel Dekker Incorporated.

Rooke, J. A. (1985). The nutritive value of feed proteins and feed protein residues resistant to degradation by rumen microorganisms. Journal of Science of Food and Agriculture 36, 629-637.

Rooke, J. A. Greife, H. A. \& Armstrong, D. G. (1984). The effect of in sacco rumen incubation of a grass silage upon the total and D-amino acid composition of the residual silage dry matter. Journal of Agricultural Science, Cambridge 102, 695-702.

Rulquin, H. \& Vérité, R. (1993). Amino acid nutrition of dairy cows: Productive effects and animal requirements. In Recent Advances in Animal Nutrition, pp. 55-77 [P. C. Garnsworthy and D. J. A. Cole, editors]. Loughborough: Nottingham University Press.

Schwab, C. G., Bozak, C. K., Whitehouse, N. L. \& Mesbah, M. M. A. (1992). Amino acid limitation and flow to duodenum at four stages of lactation. 1. Sequence of lysine and methionine limitation. Journal of Dairy Science 74, 3486-3502.

Seymour, W. M., Polan, C. E. \& Herbein, J. H. (1990). Effects of dietary protein degradability and casein or amino acid infusion on production and plasma amino acid in dairy cows. Journal of Dairy Science 73,735 748 . 
Slump, P. (1969). Characterization of the nutritive value of food proteins by amino acid composition and the effect of heat and alkali treatment on the availablity of amino acids, Thesis, University of Amsterdam, The Netherlands.

Stallings, C. C., Acosta, Y. M. \& Polan, C. E. (1991). Predicting diet protein degradability from individual ingredient estimations in the diets containing barley silages. Journal of Dairy Science 74, 3486-3491.

Steg, A., Spoelstra, S. F., Van der Meer, J. M. \& Hindle, V. A. (1990). Digestibility of grass silage. The Netherlands Journal of Agricultural Science 38, 407-422.

Stryer, L. (1988). Biochemistry. New York: Freeman and Company.

Susmel, P., Stefanon, B., Mills, C. R. \& Candido, M. (1989). Change in amino acid composition of different protein sources after rumen incubation. Animal Production 49, 375-385.

Syrjälä-Qvist, L., Pekkarinen, E., Setälä, J. \& Kangasmaki, T. (1984a). Effect of red clover/timothy ratio on the protein value and the quality of silage. Journal of Agricultural Science in Finland 56, 183-191.

Syrjälä-Qvist, L., Pekkarinen, E., Setälä, J. \& Kangasmaki, T. (1984b). Effect of nitrogen fertilization on the protein quality of timothy grass and silage. Journal of Agricultural Science in Finland 56, 193-199.

Tamminga, S. (1986). Utilization of naturally occurring NPN-compounds by ruminants. Archives of Animal Nutrition 36, 169-176.

Van Bruchem, J., Rouwers, S. M. G., Bangma, G. A., Lammers-Wienhoven, S. C. W. \& Van Adrichem, P. W. M. (1985). Digestion of proteins of varying degradability in sheep. 2. Amount and composition of the protein entering the small intestine. Netherlands Journal of Agricultural Science 33, 273-284.

van Straalen, W. M., Dooper, F. M. H., Antoniewicz, A. M., Kosmala, I. \& van Vuuren, A. M. (1993). Intestinal digestibility of protein from grass and clover in dairy cows measured with the mobile nylon bag and other methods. Journal of Dairy Science 76, 2970-2979.

van Straalen, W. M. \& Tamminga, S. (1990). Protein degradation of ruminant diets. In Feedstuff Evaluation, pp. 55-72 [J. Wiseman and D. J. A. Cole, editors]. London: Butterworths.

Van Vuuren, A. M., Krol-Kramer, F., Van der Lee, R. A. \& Corbijn, H. (1992). Protein digestion and intestinal amino acids in dairy cows fed fresh Lolium perenne with different nitrogen contents. Journal of Dairy Science 75, 2215-2225.

Varvikko, T., Lindberg, J. E., Setälä, J. \& Syrjälä-Qvist, L. (1983). The effect of formaldehyde treatment of soya-bean meal and rapeseed meal on amino acid profiles and acid-pepsin solubility of rumen undegraded protein. Journal of Agricultural Science, Cambridge 101, 603-612.

Varvikko, T. \& Vanhatalo, A. (1991). Intestinal nitrogen degradation of hay and grass silage estimated by the mobile nylon bag technique. World Review of Animal Production 16, 73-76.

Voigt, J., Piatkowski, B., Engelman, H. \& Rudolph, E. (1985). Measurement of postruminal digestibility of crude protein by the bag technique in cows. Archive für Tierernährung 35, 555-562.

Webster, A. J. F., Kitcherside, M. A., Keirby, J. R. \& Hall, P. A. (1984). Evaluation of protein feeds for dairy cows. Animal Production 38, 548.

Weakley, D. C., Stern, M. D. \& Satter, L. D. (1983). Factors affecting disappearance of feedstuffs from bags suspended in the rumen. Journal of Animal Science 56, 493-507. 
Throughout the year, The Nutrition Society holds important meetings and symposia, often in collaboration with other learned societies, where international experts are invited to speak on topics of particular interest in nutritional science.

\section{Editor: K M Younger} Dublin, Ireland

\section{Proceedings of The} Nutrition Society

The 1997 volume will feature papers presented at the following symposia:

- Food industry, nutrition and public health

- Diabetes towards the year 2000

- Nutrition in wild and captive animals

- Nutritional issues for women

- Postprandial lipid metabolism

- Assessment of nutritional status in disease and other trauma

- Nutritional aspects of bone

All this key information can be at your finger tips during 1997 by subscribing to the Proceedings of The Nutrition Society.

ISSN: $00296651 \quad 1997$, Volume 56 $£ 165.00$ (US\$295.00 Americas only)

\section{Ranked 6th out of 44 in the SCI Journal Citation Report of Nutrition \& Dietetics Journals (1994)}

Order your 1997 subscription now!

CAB INTERNATIONAL

Wallingford, Oxon, OX10 8DE, UK

Tel: +44 (0)1491 832111

Fax: 44 (0)1491 826090

E-mail: marketing@cabi.org

CAB INTERNATIONAL

198 Madison Avenue,

New York, NY10016, USA

Tel: +1 (212) 7266490

or +1 (212) 7266491

Toll-free: 18005284841

Fax: +1 (212) 6867993

CAB INTERNATIONAL

E-mail: cabi-nao@cabi.org 